Review

\title{
Withholding Certificates and Self-Certifications under FATCA-Part II
}

\author{
Stefan Kaestli \\ Institute of Economics of the Polish Academy of Sciences, Warsaw, Poland
}

Article history

Received: 10-10-2015

Revised: $10-11-2015$

Accepted: 16-01-2016

Email: stefan.kaestli@kaestli.name

\begin{abstract}
This review article analyzes and explains the formal requirements for a withholding certificate (or any acceptable substitute) to be valid under the Foreign Account Tax Compliance Act (FATCA). It is an addition to the already published article "Withholding Certificates and SelfCertifications under FATCA".
\end{abstract}

Keywords: FATCA, Chapter 4, Withholding Certificate, Self-Certification, Documentary Evidence, Self-Declaration

\section{Introduction}

The main goal of the FATCA regulation consists in gathering data of financial accounts held by U.S. tax residents living outside the United States. An integral part of that process is the documentation of each account holder's FATCA status (hereafter: chapter 4 status). A participating FFI (hereafter: PFFI), including a reporting Model 1 FFI, may establish the status of each account on a withholding certificate or self-certification.

The already published article "Withholding Certificates and Self-Certifications under FATCA" (Kaestli, 2015) explains the difference between the two main categories-withholding certificate and selfcertifications and it describes how a withholding agent may create his own form which is valid for FATCA purposes.

This second article explains the requirements and periods of validity for a withholding certificate and other accepted self-certifications. Further to that, this second part elaborates on further questions that arise regarding formal requirements for a form to be valid. It also discusses two main legal loopholes; possibility to prepopulate withholding certificates and self-certifications by a U.S. withholding agent and persons who are eligible to fill-in the forms.

\section{Formal Requirements for a Form to be Valid}

\section{Pre-Population of Information}

The Treasury Regulations are completely silent on the question whether an FFI is allowed to pre-populate certain information in a paper-based withholding certificate or self-certification. One cannot find such information anywhere in the law, basically no literature exists and it seems that there were no legal cases on this topic settled. U.S. tax advisors would generally advice against pre-populating withholding certificates, whilst advisors and withholding agents outside the United States are more relaxed on this issue. To conclude: pre-populating information in a withholding certificate of self-certification form is at least not something that is typically done by a U.S. withholding agent (Perryman, 2015). For that reason, it is not advisable for a U.S. withholding agent in the form of a PFFI to pre-populate any information than account numbers and maybe an account holder's name. The fact that the German authorities explicitly allow German financial institutions to pre-populate self-certifications (BMF, 2015) should not be seen as an allowance for PFFIs because German FFIs are governed under a M2 IGA and therefore, self-certifications issued by German FFIs are subject to local German law whereas such selfcertifications that are issued by PFFIs are subject to U.S. law. Interestingly, German FFIs must not pre-populate any information on the account holder's tax residency and chapter 4 status.

If a U.S. withholding agent or a qualified intermediary maintains an electronic W-8 system (hereafter: EW-8), such an EW-8 is expected to prepopulate a client's U.S. or foreign TIN if such information is available in the withholding agent's records (IRS, 2015b; 2015c). An EW-8 is permitted to pre-populate a client's name, permanent resident address and mailing address provided that all address fields are included as separate fields and under the condition that the user confirms each such information from a dropdown menu against the information that is in the 
withholding agent's records. All other information that is not specifically mentioned above is not allowed to prepopulate in an EW-8. Upon renewal of a selfcertification, an EW-8 is allowed to pre-populate all fields but the signature provided the user confirms separately all pre-populated fields.

\section{Persons who May Fill in the Information in a Withholding Certificate}

It is not mentioned in the Treas. Reg. whether an FFI is allowed to support its account holders by filling in information in a withholding certificate. U.S. tax specialists are unanimously of the opinion that it is the account holder who must declare his FATCA status without the help of the FFI. For that reason, it is highly advisable to a withholding agent not to support his clients by filing in any information in a withholding certificate or a self-certification. In practice, most withholding agents develop some kind of guidance which explains how to fill-in such forms and/or they explain the terms in an appendix to a form.

\section{Persons who May Sign the Withholding Certificate or Written Statement}

A withholding certificate (including an acceptable substitute) or written statement may be signed by any person authorized to sign a declaration under penalties of perjury on behalf of the person whose name is on the certificate or written statement, as provided in sections 6061 through 6063 and the regulations thereunder. A person authorized to sign a withholding certificate or written statement includes an officer or director of a corporation, a partner of a partnership, a trustee of a trust, an executor of an estate, any foreign equivalent of the former titles and any other person that has been provided written authorization by the individual or entity named on the certificate or written statement to sign documentation on such person's behalf (see Treas. Reg. $\S 1.1471-3(c)(6)(i)$ and Baker and McKenzie, 2014).

\section{Electronic Transmission and Electronic Signature}

A withholding agent may accept a withholding certificate (including an acceptable substitute form), a written statement or other such form as the IRS may prescribe, electronically in accordance with the requirements set forth in $\S 1.1441-1(\mathrm{e})(4)(\mathrm{iv})$ (see Treas. Reg. §1.1471-3T(c)(6)(iv)).

The IRS electronic transmission regulations under IRC Section 1471 and 1441 allow a withholding agent to accept withholding certificates and written statements that are scanned and received electronically provided that; (i) the exact same information is on the paper form are provided, (ii) the perjury statement is the same as on the paper form and (iii) the electronic signature is effected by the person whose name is on the form. The electronic signature can be in any form that satisfies the foregoing requirements and provided that the electronic signature is the final entry in the person's form submission (see $\$ 1.1441-1($ e)(4)(iv)).

The option to electronically transmit withholding certificates was unambiguously confirmed by the IRS on 14 August 2015. The IRS issued guidance allowing taxpayers to scan forms into an image or PDF file and send a link to the withholding agent so that the agent can download the valid W-8 form (IRS, 2015a).

All the aforementioned rules on electronic transmission and electronic signatures apply to withholding certificates, written statements and documentary evidence alike (see Treas. Reg. §1.1471-3(c)(6)(iv)).

U.S. withholding agents (e.g., in the form of a PFFI) are not required to have an EW-8 approved by the IRS but for peace of mind, they are highly advised to apply for an Electronic W-8 Memorandum of Understanding with the IRS (IRS, 2014).

\section{Record Retention for Documentary Evidence}

A withholding agent must retain each withholding certificate, written statement, or copy of documentary evidence for as long as it may be relevant for the determination of the withholding agent's tax liability under chapter 4 .

A withholding agent may retain an original, certified copy or photocopy (including a microfiche, electronic scan or similar means of electronic storage) of the withholding certificate, written statement or documentary evidence.

For each documentary evidence, the withholding agent must also note in its records the date on which the document was received and reviewed (see Treas. Reg. $\S 1.1471-3(\mathrm{c})(6)(\mathrm{iii})(\mathrm{A}))$.

\section{Missing Information/Incomplete Forms}

A withholding agent may treat a withholding certificate, written statement and documentary evidence furnished to establish an account holders chapter 4 status as valid, notwithstanding that the withholding certificate contains inconsequential errors, if the withholding agent has sufficient documentation on file to supplement the information missing from the withholding certificate due to the error. In such case, the documentation relied upon to cure the inconsequential error must be conclusive.

The term inconsequential error is merely descriptive in its nature, as the regulations mention the following examples, but provide no clear definition:

- A failure to select an entity type on a withholding certificate is not an inconsequential error if the withholding agent has an organization document for the entity that provides sufficient information to determine the person's entity type if the person was eligible to make an election under $\$ 301.7701-3(c)(1)(i)$ 
- An abbreviated country code may be an inconsequential error if the withholding agent has government issued identification for the person from a country that reasonably matches the abbreviation, but it may not be a consequential error if the abbreviation on the form does not reasonably match the country of residence in the person's passport

- A missing date on a withholding certificate may also be an inconsequential error that can be cured by the withholding agent receiving the form (see Treas. Reg. §1.1471-3(c)(7)(i))

- A missing country, missing signature or a failure to make the required certification is clearly a consequential error that must not be cured by the withholding agent receiving the form (IRS, 2013: Summary of Comments and Explanation of Revisions IV(IV)(A)(5))

A payee may decide not to fill in information in part I (4) of a W-8BEN-E form. Chapter 3 information is not needed to reasonably determine a payee's chapter 4 status. If a payee does not fill in information in part I (5) of a W-8BEN-E form, he may be treated as a recalcitrant account holder or nonparticipating FFI and be subject to a $30 \%$ withholding on with hold able payments (IRS, 2014).

\section{Validity Period of Withholding Certificates, Written Statements, Self-Certifications and Documentary Evidences}

\section{General Rule $=3$ Year Rule}

Except as provided otherwise, a withholding certificate or written statement will remain valid until the last day of the third calendar year following the year in which it is signed (see Treas. Reg. §1.14713(c)(6)(ii)(A)) (hereafter: Three-year-rule). As an example, a withholding certificate that was signed on 21 January 2015 will remain valid until 31 December 2018. Nevertheless, documentary evidence that contains an expiration date may be treated as valid until that expiration date if doing so would provide a longer period of validity than the three-year period (see Treas. Reg. $\S 1.1471-3(\mathrm{c})(6)(\mathrm{ii})(\mathrm{A}))$.

\section{Change in Circumstances}

A withholding certificate, written statement and documentary evidence will cease to be valid if the withholding agent has knowledge of a change in circumstances that makes the information on the documentation incorrect (see Treas. Reg. §1.14713(c)(6)(ii)(A)).

Not all changes in circumstances are relevant to an account holder's chapter 4 status. As an example, a change of address from Liechtenstein to Switzerland does not change an account holders chapter 4 status, whereas a relocation from Liechtenstein to the United States becomes relevant (see Treas. Reg. §1.1471$3(\mathrm{c})(6)(\mathrm{ii})(\mathrm{E})(1))$.

A withholding agent is required to notify any person providing documentation of the person's obligation to notify the withholding agent of a change in circumstances (see Treas. Reg. §1.1471-3(c)(6)(ii)(A)). If a change in circumstances makes any information on a certificate or other documentation incorrect, then the person whose name is on the certificate or other documentation must inform the withholding agent within 30 days of the change and furnish a new certificate, a new written statement, or new documentary evidence (see Treas. Reg. §1.1471-3(c)(6)(ii)(E)(2)).

\section{Exception from the General Rule-Indefinite Validity}

\section{Indefinite Validity in General}

A withholding certificate, written statement and documentary evidence shall remain valid until the withholding agent has knowledge of a change in circumstances that makes the information on the documentation incorrect (see Treas. Reg. §1.14713(c)(6)(ii)(B)). In other words, in lieu of the general 3year-rule, a withholding certificate or written statement can become indefinitely valid (hereafter: Evergreen) under certain circumstances.

Typical situations in which such forms are evergreen include; (i) if an FFI does not allow an account holder to hold US assets or (ii) if a PFFI assures that there is no U.S. FDAP paid to an account holder (e.g., if a fund invests solely in non-U.S. assets).

Table 1 shows in which cases withholding certificates, written statements and documentary evidences remain generally valid for an indefinite period. In most cases, a withholding certificate, written statement and documentary evidence is evergreen in spite of the general 3-year-rule.

\section{Indefinite Validity in the Case of Certain Offshore Obligations}

A withholding certificate, written statement and documentary evidence provided with respect to an offshore obligation shall remain valid until the withholding agent has knowledge of a change in circumstances that makes the information on the documentation incorrect (see Treas. Reg. §1.1471$3(\mathrm{c})(6)(\mathrm{ii})(\mathrm{C}))$. In other words, in lieu of the general 3year-rule, a withholding certificate or written statement can become evergreen under certain circumstances. The term offshore obligation means an offshore obligation defined in $\$ 1.6049-5(c)(1)$, by substituting the terms withholding agent or financial institution for the term payor (see Treas. Reg. §1.1471-1T(b)(88)). 
Table 1. Indefinite validity of withholding certificates, written statements and documents

\begin{tabular}{|c|c|c|c|c|}
\hline Document provided by & $\begin{array}{l}\text { Withholding } \\
\text { Certificate }\end{array}$ & $\begin{array}{l}\text { Written } \\
\text { Statement }\end{array}$ & $\begin{array}{l}\text { Documentary } \\
\text { Evidence }\end{array}$ & $\begin{array}{l}\text { Treasury } \\
\text { Regulations }\end{array}$ \\
\hline Participating FFI & $\mathrm{X}$ & $\mathrm{X}$ & & $\S 1.1471-3(\mathrm{c})(6)(\mathrm{ii})(\mathrm{B})(1)$ \\
\hline Registered Deemed Compliant FFI & $\mathrm{X}$ & $\mathrm{X}$ & & $\S 1.1471-3(\mathrm{c})(6)(\mathrm{ii})(\mathrm{B})(1)$ \\
\hline Individual "without certain U.S. indicia" claiming foreign status & $\mathrm{X}$ & & $\mathrm{X}$ & $\S 1.1471-3(\mathrm{c})(6)(\mathrm{ii})(\mathrm{B})(2)$ \\
\hline $\begin{array}{l}\text { Retirement fund } \\
\text { (described in Treas. Reg. } \$ 1.1471-6(f))\end{array}$ & $\mathrm{X}$ & & $\mathrm{X}$ & $\S 1.1471-3(\mathrm{c})(6)(\mathrm{ii})(\mathrm{B})(3)$ \\
\hline $\begin{array}{l}\text { Excepted nonfinancial group entity } \\
\text { (described in Treas. Reg. } \S 1.1471-5(\mathrm{e})(5)(\mathrm{i}))\end{array}$ & $\mathrm{X}$ & & $\mathrm{X}$ & $\S 1.1471-3(\mathrm{c})(6)(\mathrm{ii})(\mathrm{B})(3)$ \\
\hline $\begin{array}{l}\text { Non-profit organization } \\
\text { (described in Treas. Reg. } \S 1.1471-5(\mathrm{e})(5)(\mathrm{vi}) \text { ) }\end{array}$ & $\mathrm{X}$ & & $\mathrm{X}$ & $\S 1.1471-3(\mathrm{c})(6)(\mathrm{ii})(\mathrm{B})(3)$ \\
\hline Non-reporting IGA FFI & $\mathrm{X}$ & & $\mathrm{X}$ & $\S 1.1471-3(\mathrm{c})(6)(\mathrm{ii})(\mathrm{B})(3)$ \\
\hline Territory financial institution & $\mathrm{X}$ & & $\mathrm{X}$ & $\S 1.1471-3(\mathrm{c})(6)(\mathrm{ii})(\mathrm{B})(3)$ \\
\hline $\begin{array}{l}\text { NFFE whose stock is regularly traded } \\
\text { (described in Treas. Reg. } \$ 1.1472-1(\mathrm{c})(1)(\mathrm{i}))\end{array}$ & $\mathrm{X}$ & & $\mathrm{X}$ & $\S 1.1471-3(\mathrm{c})(6)(\mathrm{ii})(\mathrm{B})(3)$ \\
\hline $\begin{array}{l}\text { NFFE affiliate } \\
\text { (described in Treas. Reg. } \S 1.1472-1(c)(1)(\text { ii)) }\end{array}$ & $\mathrm{X}$ & & $\mathrm{X}$ & $\S 1.1471-3(\mathrm{c})(6)(\mathrm{ii})(\mathrm{B})(3)$ \\
\hline Active NFFE & $\mathrm{X}$ & & $\mathrm{X}$ & $\S 1.1471-3(\mathrm{c})(6)(\mathrm{ii})(\mathrm{B})(3)$ \\
\hline $\begin{array}{l}\begin{array}{l}\text { Sponsored FFI } \\
\text { (described in Treas. Reg. } \S 1.1471-5(\mathrm{f})(2)(\mathrm{iii}))\end{array} \\
\end{array}$ & $\mathrm{X}$ & & $\mathrm{X}$ & $\S 1.1471-3(\mathrm{c})(6)(\mathrm{ii})(\mathrm{B})(3)$ \\
\hline Intermediary, flow-through entity, or U.S. branch & $\mathrm{X}$ & & & $\S 1.1471-3(\mathrm{c})(6)(\mathrm{ii})(\mathrm{B})(4)$ \\
\hline $\begin{array}{l}\text { Foreign government, government of a U.S. territory, foreign } \\
\text { central bank, international organization } \\
\text { (Including an entity that is wholly owned by any such entities } \\
\text { and including the Bank for International Settlements) }\end{array}$ & $\mathrm{X}$ & $\mathrm{X}$ & $\mathrm{X}$ & $\S 1.1471-3(\mathrm{c})(6)(\mathrm{ii})(\mathrm{B})(5)$ \\
\hline Documentary evidence that is not generally renewed or amended & & & $\mathrm{X}$ & $\S 1.1471-3(\mathrm{c})(6)(\mathrm{ii})(\mathrm{B})(6)$ \\
\hline $\begin{array}{l}\text { Section 501(c) entity } \\
\text { (described in Treas. Reg. } \S 1.1471-5(\mathrm{e})(\mathrm{v}))\end{array}$ & $\mathrm{X}$ & & & $\S 1.1471-3(\mathrm{c})(6)(\mathrm{ii})(\mathrm{B})(7)$ \\
\hline
\end{tabular}

Table 2. Indefinite validity of withholding certificates, written statements and documents for offshore obligations

\begin{tabular}{|c|c|c|c|c|}
\hline Document provided by & $\begin{array}{l}\text { Withholding } \\
\text { certificate }\end{array}$ & $\begin{array}{l}\text { Written } \\
\text { statement }\end{array}$ & $\begin{array}{l}\text { Documentary } \\
\text { evidence }\end{array}$ & $\begin{array}{l}\text { Treasury } \\
\text { regulations }\end{array}$ \\
\hline Individual "without certain U.S. indicia" claiming foreign status & $\mathrm{X}$ & & $\mathrm{X}$ & $\S 1.1471-3(\mathrm{c})(6)(\mathrm{ii})(\mathrm{C})(1)$ \\
\hline Retirement fund & $\mathrm{X}$ & & $\mathrm{X}$ & $\S 1.1471-3(\mathrm{c})(6)(\mathrm{ii})(\mathrm{C})(2)(\mathrm{i})$ \\
\hline Excepted nonfinancial group entity & $\mathrm{X}$ & & $\mathrm{X}$ & $\S 1.1471-3(\mathrm{c})(6)(\mathrm{ii})(\mathrm{C})(2)(\mathrm{ii})$ \\
\hline Section 501(c) entity & $\mathrm{X}$ & & & $\S 1.1471-3(\mathrm{c})(6)(\mathrm{ii})(\mathrm{C})(2)(\mathrm{iii})$ \\
\hline Non-profit organization & $\mathrm{X}$ & & $\mathrm{X}$ & $\S 1.1471-3(\mathrm{c})(6)(\mathrm{ii})(\mathrm{C})(2)(\mathrm{iv})$ \\
\hline Non-reporting IGA FFI & $\mathrm{X}$ & & $\mathrm{X}$ & $\$ 1.1471-3(\mathrm{c})(6)(\mathrm{ii})(\mathrm{C})(2)(\mathrm{v})$ \\
\hline Territory financial institution & $\mathrm{X}$ & & $\mathrm{X}$ & $\S 1.1471-3(\mathrm{c})(6)(\mathrm{ii})(\mathrm{C})(2)(\mathrm{vi})$ \\
\hline NFFE whose stock is regularly traded & $\mathrm{X}$ & & $\mathrm{X}$ & $\S 1.1471-3(\mathrm{c})(6)(\mathrm{ii})(\mathrm{C})(2)(\mathrm{vii})$ \\
\hline NFFE affiliate & $\mathrm{X}$ & & $\mathrm{X}$ & $\S 1.1471-3(\mathrm{c})(6)(\mathrm{ii})(\mathrm{C})(2)(\mathrm{viii})$ \\
\hline Active NFFE & $\mathrm{X}$ & & $\mathrm{X}$ & $\$ 1.1471-3(\mathrm{c})(6)(\mathrm{ii})(\mathrm{C})(2)(\mathrm{ix})$ \\
\hline Sponsored FFI & $\mathrm{X}$ & & $\mathrm{X}$ & $\S 1.1471-3(\mathrm{c})(6)(\mathrm{ii})(\mathrm{C})(2)(\mathrm{x})$ \\
\hline Owner-documented FFI & $\mathrm{X}$ & $\mathrm{X}$ & $\mathrm{X}$ & $\$ 1.1471-3(\mathrm{c})(6)(\mathrm{ii})(\mathrm{C})(3)+(4)$ \\
\hline $\begin{array}{l}\text { Passive NFFE or an excepted territory NFFE } \\
\text { (not including high value accounts) }\end{array}$ & $\mathrm{X}$ & & & $\S 1.1471-3(\mathrm{c})(6)(\mathrm{ii})(\mathrm{C})(5)$ \\
\hline
\end{tabular}

Table 2 shows in which cases withholding certificates, written statements and documentary evidences remain valid for an indefinite period in the case of offshore obligations.

\section{Validity if a Reduced Withholding Rate is Claimed}

A withholding certificate furnished to a withholding agent to claim a reduced rate of withholding for income that is effectively connected with the conduct of a trade or business within the United States shall be limited to the three-year period (see Treas. Reg. §1.14713(c)(6)(ii)(D)). Such a limitation would only apply for chapter 3 purposes but it would not limit the forms validity for chapter 4 purposes.

It also means that a withholding certificate that declares an account holder's chapter 3 status but that is not used to claim a reduced withholding rate under chapter 3 remains evergreen under both chapters 3 and 4 .

\section{Validity of Self-Certifications}

The Treasury Regulations and the Intergovernmental Agreements are silent on the validity and formal requirement of "acceptable self-certifications for purposes of the Annex I due diligence procedures for preexisting and new accounts" (self-certifications) (IGA CH-USA, 2015; IGA M1, 2014; IGA M2, 2014).

U.S. legal advisors generally interpret the silence in a way that self-certifications would follow the same rules as withholding certificates, while non-U.S. legal advisors are generally of the opinion that self-certifications remain evergreen until a change of circumstances. The UK authorities follow the latter argument by saying a self-certification used to establish an account holder's chapter 4 status will remain valid indefinitely subject to a change in circumstance resulting in a change of the account holder's status (HRMC, 2015). 


\section{Summary/Conclusion}

Withholding certificates, written statement and documentary evidences have different validity periods.

Documentary evidence is generally valid until its expiration date. It becomes evergreen if it does not have an expiration date. Some documentary evidence may become evergreen for purposes of chapter 4 despite having an expiration date and/or despite for expiring for chapter 3 purposes. The IRS may determine such exceptions in the Treasury Regulations.

Withholding certificates and written statements are generally valid until the last day of the third calendar year following the year in which they were is signed. The general 3-year-rule is always applicable if a payee claims a reduced withholding rate under chapter 3 . A withholding certificate may also remain indefinitely valid for chapter 3 purposes when no reduced withholding rate is claimed.

Both the IGA and Treasury Regulations are silent on the validity periods for self-certifications. Market participants are not equally convinced whether self-certifications would follow the same rules as withholding certificates or whether they remain indefinite valid.

A withholding certificate, written statement, documentary evidence or self-declaration will cease to be valid if the withholding agent has knowledge of a change in circumstances that makes the information on the documentation incorrect.

\section{Acknowledgment}

There is no source of financial support, no financial support or relationships that may pose conflict of interest and no technical assistance from anyone.

\section{Funding Information}

There are no funders of this manuscript, it is all the authors work and he did not get any funds from anyone.

\section{Author's Contributions}

The whole review article is my own work without contribution from any other person.

\section{Ethics}

I hereby certify that no part of manuscript reporting original work is being considered for publication in whole or in part elsewhere but in my $\mathrm{PhD}$ dissertation.

\section{References}

Baker and McKenzie, 2014. FATCA coordinating regulations. Client Alert, Baker and McKenzie, Chicago.
BMF, 2015. Automatischer information saustausch mit den vereinigten staaten von amerika, anwendungs fragen im zusammenhang mit dem fatca-abkommen, Dokument 2015/0544945. Bundesministerium der Finanzen.

HRMC, 2015. Implementation of the international tax compliance (United States of America) regulations 2014. Guidance Notes, HM Revenue and Customs.

IGA CH-USA, 2015. Agreement between the United States of America and Switzerland for cooperation to facilitate the implementation of FATCA. abkommen zwischen der schweiz und den vereinigten staaten von Amerika über die Zusammenarbeit für eine erleichterte Umsetzung von FATCA. SR 0.672.933.63.

IGA M1, 2014. Model 1A IGA reciprocal, preexisting TIEA or DTC. Agreement between the Government of the United States of America and the Government of [FATCA Partner] to Improve International Tax Compliance and to Implement FATCA, U.S. Department of the Treasury.

IGA M2, 2014. Model 2 IGA, Preexisting TIEA or DTC. Agreement between the Government of the United States of America and the Government of [FATCA Partner] to Improve International Tax Compliance and to Implement FATCA, U.S. Department of the Treasury.

IRS, 2013. Internal Revenue Bulletin 2013-15, T.D. 9610. Internal Revenue Service.

IRS, 2014. Instructions for Form W-8BEN-E-What's New, FATCA, page 1. Department of the Treasury, Internal Revenue Service.

IRS, 2015a. FATCA-FAQs general, General Compliance, Q11. Internal Revenue Service, Internet, Last Updated.

IRS, 2015b. U.S. Withholding agent frequently asked questions, Question 40. Internal Revenue Service, Internet, Last Updated.

IRS, 2015c. Qualified intermediary frequently asked questions. Question 8. Internal Revenue Service, Internet, Last Updated.

Kaestli, S., 2015. Withholding certificates and selfcertifications under FATCA. Am. J. Econom. Bus. Administrat., 7: 68-76. DOI: 10.3844/ajebasp.2015.68.76

Perryman, H., 2015. Guide to GATCA. Internet, version 3.14 .

Treas. Reg. 26 United States Code $\S \S ~ 1.1471-1.1474$, Treasury Regulations, Department of the Treasury, Internal Revenue Service, n.d. 